\title{
VENTURIELLA SINENSIS (ERPODIACEAE, BRYOPHYTA), A NEW SPECIES AND A NEW FAMILY FOR THE MOSS FLORA OF RUSSIA
}

\author{
VENTURIELLA SINENSIS (ERPODIACEAE, BRYOPHYTA), \\ НОВЫЙ ВИД И НОВОЕ СЕМЕЙСТВО ДЛЯ ФЛОРЫ МХОВ РОССИИ
}

\author{
Vladimir E. Fedosov ${ }^{1}$, Olga Yu. PisARENKO ${ }^{2}$, VAdim A. BAKAlin ${ }^{3}$ \& ElENA A. IGNATOVA ${ }^{1}$ \\ ВЛАДИМИР Э. ФЕДОСОВ ${ }^{1}$, ОЛЬГА Ю. ПИСАРЕНКО ${ }^{2}$, ВАДИМ А. БАКАЛИН ${ }^{3}$, ЕЛЕНА А. ИГНАТОВА ${ }^{1}$
}

Abstract

\begin{abstract}
Venturiella sinensis (Venturi) Müll. Hal., the species with temperate amphipacific distribution was recently found on Mt. Sinyaya (the East Manchurian Mountains, south of Primorskij Territory, the Russian Far East). The description and illustrations of the species based on the Russian specimen are provided, its ecology and distribution are considered. Though the present record of the species is not surprising, it provides a remarkable extension of the Russian moss flora as the first representative of the generally tropic family Erpodiaceae. The Manchurian mountains represent the easternmost distribution limit of several species of vascular plants and liverworts with generally southern distribution.
\end{abstract}

Резюме

\begin{abstract}
Venturiella sinensis (Venturi) Müll. Hal., вид, распространенный преимущественно в восточной Азии и на западе Северной Америки, недавно найден близ горы Синяя (Восточно-Маньчжурские горы, юг Приморского края). Приводятся описание и иллюстрации вида, основанные на российском образце, рассмотрены его экология и распространение. Хотя настоящая находка вполне ожидаема, это заметное дополнение к флоре мхов России, для которой ранее не приводилось представителей преимущественно тропического семейства Erpodiaceae. K Восточно-маньчжурским горам приурочены восточные границы распространения целого ряда преимущественно более южных видов растений, не проникающих на Сихоте-Алинь.
\end{abstract}

KEYWORDS: Erpodiaceae, Russia, Far East, Primorskij Territory, flora, rare species, Manchuria

\section{INTRODUCTION}

Extensive exploration of the moss flora of Primorskij Territory resulted in numerous records of species with generally southern distribution, including Fissidens hyalinus Wilson \& Hooker (Ignatov et al., 2007), Homaliadelphus targionianus (Mitt.), Dixon \& P. Vard., Neckera konoi Broth. ex Cardot, N. polyclada Müll. Hal., N. goughiana Mitt. (Ignatova et al., 2009), and Ephemerum spinulosum Bruch \& Schimp. (Ignatov et al., 2013). At the same time, collecting activity was mostly concentrated on the Sikhote-Alin Mt. Range, whereas bryophyte flora of the East Manchurian Mountains situated westward and separated from the Sikhote-Alin by the Khanka lowland, was hitherto insufficiently explored.

The East Manchurian Mountains is a mountain area at the western spoors of the Changbai Range with the highest point in Paektu Mt. (Changbai) at $2744 \mathrm{~m}$ a.s.l. Spreading eastward, the Manchurian mountains become lower and disappear near the Khanka lowland in the southern fridge of the Russian Far East. Within the Russian Far East, these spoors stretch from the Khanka Lake shore in the north to the Tumangan River mouth near the border with North Korea. In their Russian part, the East Manchurian Mts. are low (mostly not higher than 600-700 m a.s.l.), broadleaved forested, commonly with numerous rock outcrops. Unique liverwort records made there by Bakalin motivated us for a field trip with the aim of the moss flora exploration. Thus, we have recently visited Sinyaya Mt. one of the highest points of the East Manchurian Mts. within Russia. Among others, a remarkable epiphytic moss was collected there. It attracted our attention in the field due to its habitual similarity with Orthotrichum diaphanum Brid., the species unknown in Siberia, the Russian Far East and China. However, further microscopic study revealed that the specimen contains Venturiella sinensis (Venturi) Müll. Hal. from monotypic genus, being classified in the family Erpodiaceae Broth. previously unknown in Russia, and thus providing a matter for the present paper.

1 - Lomonosov Moscow State University, Faculty of Biology, Geobotany Dept., Leninskie Gory Str. 1-12, Moscow 119234 Russia - Россия, 119234, Москва, Ленинские Горы, д. 1 стр. 12, Московский государственный университет, биологический факультет, кафедра геоботаники; emails: fedosov_v@mail.ru, arctoa@list.ru

2 - Central Siberian Botanical Garden, Zolotodolinsk̄aya 101, Novosibirsk 630090 Russia - Россия 630090 Новосибирск, Золотодолинская, 101, Центральный Сибирский ботанический сад СО PAH; email: o pisarenko@mail.ru

3 - Botanical Garden-Institute, Makovskogo street, 142, Vladivostok 690024, Russia - Россия,690024, Владивосток, ул. Маковского, 142, Ботанический сад-институт ДВО РАН; email: vabakalin@gmail.com 
Venturiella sinensis (Venturi) Müll. Hal., Linnaea 39: 422. 1875. - Erpodium sinense Venturi, Bryotheca Eur. 25: 1211. 1873. - V. japonica (Mitt.) Broth., Hedwigia 38: 225. 1899. - E. japonicum Mitt., J. Linn. Soc., Bot. 22: 314. 1886.

Fig. 1.

Plants minute, dark green, creeping along bark, with ascending, lighter colored shoots. Stem with differentiated central strand, bearing brownish rhizoids on scarcely differentiated ventral surface of its plagiotropic portion, julaceous in ascending distal portions, densely foliated, irregularly or pinnately branched. Leaves imbricate, erect when dry, spreading when wet, $0.5-1 \times 0.25-0.5 \mathrm{~mm}$ in creeping shoots, $1.4-2.0 \times 0.5-0.7 \mathrm{~mm}$ in ascending shoots, from ovate base abruptly or gradually (in upper leaves) narrowed into hyaline acumen $0.1-0.7 \mathrm{~mm}$ long, reaching the half of leaf length in upper leaves, flat or twisted in upper leaves, serrulate; margins flat, mostly entire (excepting acumen); ecostate; upper laminal cells (43-)50-90(-106) $\times 18-30 \mu \mathrm{m}$, elongate-hexagonal to elongate-rhomboidal, smooth, thin-walled or slightly collenchimatose, gradually or abruptly transiting to linear, thick-walled cells of hyaline acumen, in proximal part along margins in several rows quadrate, rounded-quadrate and transversely rectangular, (14-)18-26×25-35 $\mu \mathrm{m}$, slightly collenchimatose, in 1-2 marginal rows often with slightly thickened transverse walls. Cladoautoicous. Perichaetial leaves pale, sheathing, similar to lower leaves of ascending shoots. Setae short, ca. $0.5-0.7 \mathrm{~mm}$, straight. Capsules 1-1.2 mm long, immersed, erect, symmetric, short cylindrical, pale yellow, smooth to irregularly longitudinally rugose, with numerous unicellular stomata in proximal half; exothecial cells rectangular, rather thinwalled; annulus 59-74 $\mu \mathrm{m}$ wide, persistent, composed of 3-4 rows of hyaline, inflated, elliptic cells; peristome haplolepideous, of 16 well developed, undivided, narrow-triangular, papillose, orange teeth up to $200 \mu \mathrm{m}$ long, spreading to reflexed when dry; operculum bright orange, conic-rostrate. Calyptrae campanulate, almost fully covering capsules, lobed at base, plicate, with serrate plicae, naked. Spores large, 33-40 $\mu \mathrm{m}$, papillose.

Variation. North American specimens of $V$. sinensis were segregated in a separate variety, angusti-annulata Griffin due to the difference in width of annuli, 57-69 $\mu \mathrm{m}$ in North American plants vs. $69-129 \mu \mathrm{m}$ in Asian plants, and the shape of distal tiers of annular cells, which are quadrate to octagonal in American plants vs. ellipsoidal to rhomboidal in Asian plants (Pursell \& Allen, 2007). In this respect Russian specimen corresponds to "American" var. angusti-annulata rather than to East Asian type variety, though the studied Japanese specimen had annuli ca. 63-66 $\mu \mathrm{m}$ wide, and thus, fitted to "var. angusti-annulata" as well. At the same time, our specimen remarkably differs from American population both in capsule length and spore size, the only remaining distinctive characters between var. angusti-annulata and the type variety. Rather large spores $(22-40 \mu \mathrm{m})$ ex- actly fit neither to inland Asian specimens from Korea $(25-36 \mu \mathrm{m})$ and China $(23-37.5 \mu \mathrm{m})$, nor to American specimens $(21-30 \mu \mathrm{m})$, but they correspond to Japanese specimens, where spore size varies from 21 to $45 \mu \mathrm{m}$. Likewise, capsule length in few mature capsules from our specimen is $1-1.2 \mathrm{~mm}$, less than in American plants $(1.2-1.5 \mathrm{~mm})$ and somewhat less than in Asian ones. However, a restricted number of specimens available for our study precludes an exact placement of our specimen, so we refer it to $V$. sinensis s.l.

Differentiation. By growth on tree trunks and having campanulate and plicate calyptrae, $V$. sinensis resembles species of the genus Orthotrichum, according to our field impression, especially $O$. diaphanum, which also shares with Venturiella hyaline hair points of leaves. However, creeping plants with ecostate leaves, elongatehexagonal upper leaf cells and single peristome are unique among species of the Russian moss flora. It differs from other species of the family Erpodiaceae in having smooth leaf cells and peristomate capsules.

Ecology. In newly revealed locality, the species was found on bark of Quercus mongolica in dry oak-dominated deciduous forest. Further examination of this spot of forest has not revealed any other tree colonized by the species. Griffin and Sharp (1971) noted xeric climatic conditions as characteristic for the areas inhabited by $V$. sinensis in North America, where it occurs on trunks of Acer, Ulmus, Quercus, and Juniperus, as well as on sandstone outcrops (Redfearn, 1970; Richardson, 2010). In Japan and China, $V$. sinensis is a rather common epiphytic plant in deciduous forests and in city areas (Noguchi \& Iwatsuki, 1988; Wu et al., 2011). The latter note corresponds to the observation of ecology of the whole Erpodiaceae in Yunnan (Wen-Zhang \& Shevock, 2015), where it actively colonizes deciduous trees in areas transformed by human activity and even favor some level of disturbance.

Distribution. The species occurs in East Asia (Japan, China, Korea, Taiwan and Thailand) (Noguchi \& Iwatsuki, 1988; Wu et al., 2011; Printarakul et al., 2014) and southern states of USA (Arkansas, Oklahoma and Texas), where it is represented by var. angusti-annulata (Pursell \& Allen, 2007) (Fig. 2). It is generally associated with temperate and tropic climatic conditions, but occurs neither in the Mediterranean nor in the Madrean floristic region. It penetrates northward to Jilin in China and to Hokkaido Island in Japan (Suzuki, 2016). Tan \& Iwatsuki (1996) mentioned $V$. sinensis among floristically important moss taxa. According to Iwatsuki (1972), in Japan the species avoids areas with deep snow cover; this pattern well corresponds with our finding in the East Manchurian Mts., the territory with least amount of snow within Primorsky Territory. Redfearn (1986) considered $V$. sinensis as a taxon of critical importance, which was a component of Arcto-Tertiary flora and dispersed into the Interior Highlands of USA during the Pleistocene. 


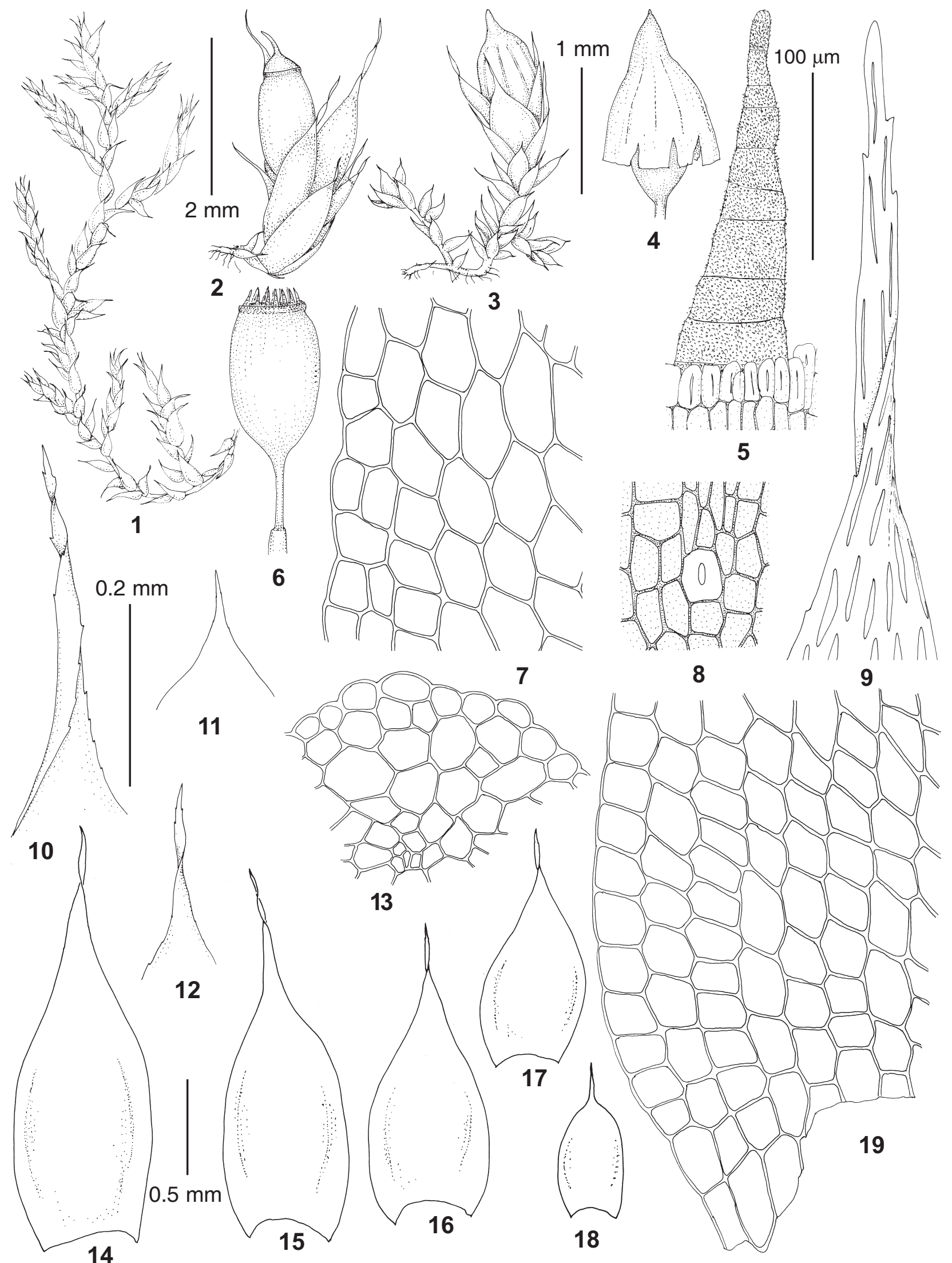

Fig. 1. Venturiella sinensis (from: Russia, Primorsky Territory, Fedosov, Pisarenko \& Bakalin s.n., MW). 1 - habit, dry; 2-3habit, wet; 4 - calyptra; 5 - peristome tooth: 6 - capsule; 7 - median leaf cells; 8 - exothecium and stoma: 9 - upper leaf cells; 10 12 - leaf apival parts; 13 - stem transverse section; 14 - perichaetial leaf; $15-18$ - stem leaves; 19 - basal leaf cells. Scale bars: $2 \mathrm{~mm}$ for $1 ; 1 \mathrm{~mm}$ for $2-4,6 ; 0.5 \mathrm{~mm}$ for $14-18 ; 0.2 \mathrm{~mm}$ for $10-12 ; 100 \mu \mathrm{m}$ for $5,7-9,13,19$. 


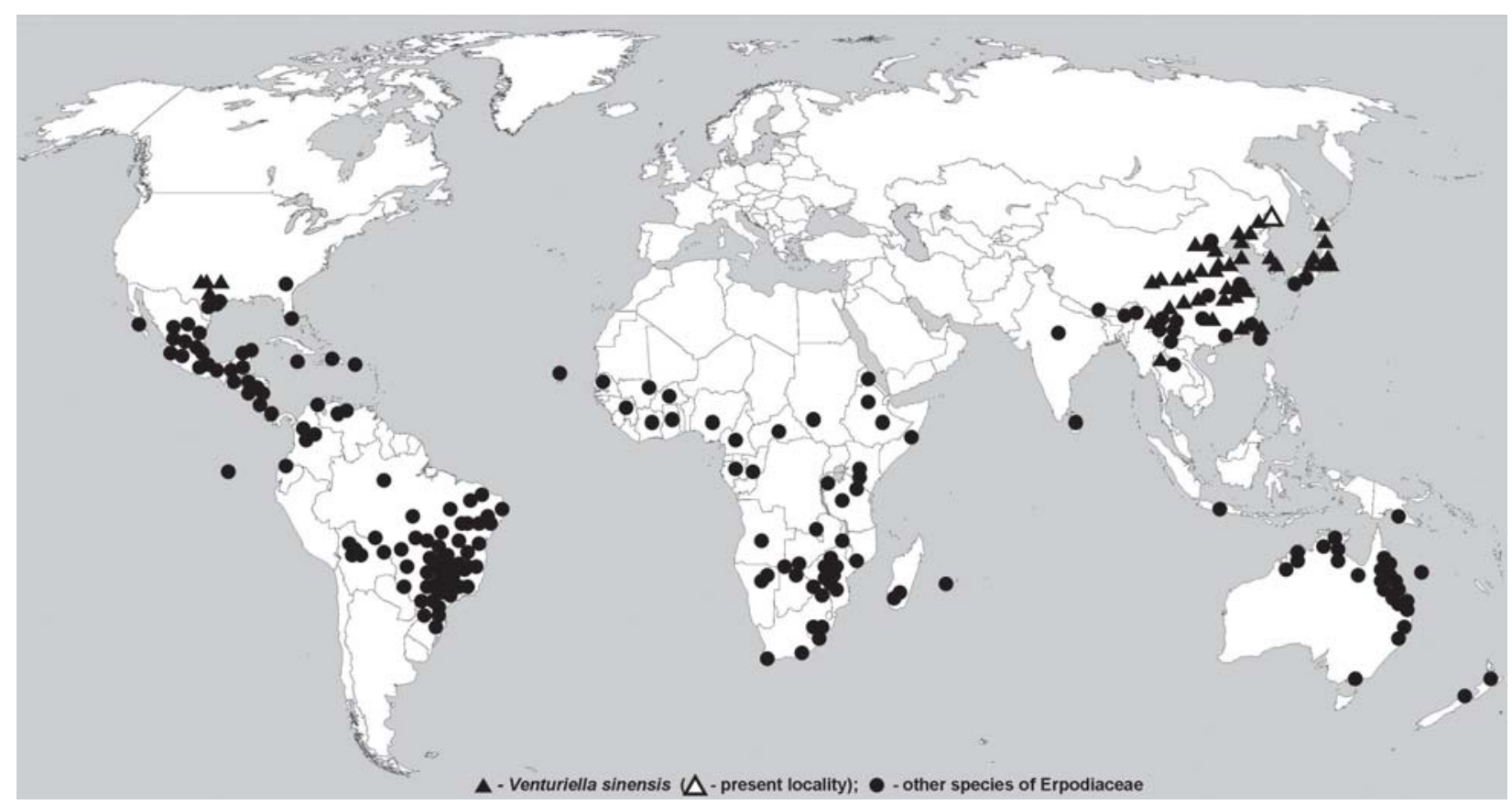

Fig. 2. Word distribution of Venturiella sinensis and general distribution of the family Erpodiaceae (based on Pursell R.A. \& B.H. Allen, 2007; O'Shea, 2006; Wang, 2011; Sharp et al., 1994, and data, published in GBIF http://www.gbif.org/species/4667 18.XII.2016).

Specimens examined: Primorsky Territory, Khankaiskij Distr., near a sharp bend in the road A183 ca. $3 \mathrm{~km}$ southward

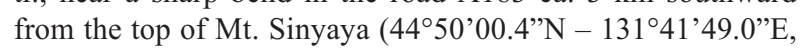
ca $350 \mathrm{~m}$. alt.), in oak dominated deciduous forest, on bark of Quercus mongolica, 23.VIII.2016, Fedosov, Pisarenko \& Bakalin s.n. (MW). S+.

Four genera are recognized in the family Erpodiaceae by most authors, including Erpodium, Venturiella, Aulacopilum and Wildia (Crum, 1972; Vitt, 1984; Goffinet et al., 2009), otherwise three latter genera are placed into one variable genus Erpodium (Stone, 1997). Species in this family share a creeping growth, pinnate branching, somewhat complanate shoots, undifferentiated costa, oblate-hexagonal leaf cells, and mitrate calyptra (De Luna, 1995). Their distribution is generally associated with tropical and subtropical regions (Fig. 2). Wen-Zhang \& Shevock (2015) note that in southern China species of the Erpodiaceae increased their occurrence in areas where urbanization of rural landscapes took place. According to their observation, moderately shaded trunks of solitary trees are an especially favorable habitat for species of the family, since moderate amount of direct sunlight contributes to their ability to compete against other bryophytes with less drought tolerance.

In general, the East Manchurian Mts. provide the house for several taxa which do not pass the Khanka lowland and do not occur in the Sikhote-Alin Mountain Range, despite potential ability to grow there due to a similar climate and landscape. In addition to the warmest climate within the Russian Far East (Ivashinnikov, 1999), the low amount of snow also contributes to climatic peculiarity of the area. This is the only place where representatives of several temperate and presumable paleotropic relict taxa of vascular plants (Cakile edentula, Cyperus tenuispica, Fimbristylis dichotoma, Hypericum laxum, Lipocarpha microcephala, Mitrasacme indica, Utricularia caerulea, Ruppia megacarpa) occur in Russia (Kozhevnikov \& Kozhevnikova, 2014) and this trend involves bryophytes as well. For instance, at least three taxa of liverworts, i.e., Cylindrocolea kiaeri (Austin) Ván̆a, Odontoschisma pseudogrosseverrucosum Gradst., S.C. Aranda \& Vanderp. and Scapania ciliata Sande Lac. are known in Russia only from the East Manchurian Mts. (Aranda et al., 2014; Choi et al., 2012; Ellis et al., 2016). The East Manchurian flora is well represented in Kedrovaya Pad' Strict Nature Reserve, that was regarded as the least disturbed area within Russian Manchuria (Vasiljev et al., 1984). The Russian part of The East Manchurian Mts. is therefore a promising area for bryological exploration. Some Manchurian taxa widely distributed in North Korea and Chinese Jilin are likely to be found there.

\section{ACKNOWLEDGEMENTS}

The work was partly supported by RFBR \# 15-3420101. We are sincerely grateful to Anna Ivanova for English correction.

\section{LITERATURE CITED}

ARANDA, S.C., S.R. GRADSTEIN, J. PATIÑO, B. LAENEN, A. DÉSAMORÉ \& A. VANDERPOORTEN. 2014. Phylogeny, classification and species delimitation in the liverwort genus Odontoschisma (Cephaloziaceae). - Taxon 63(5): 1008-1025.

CHOI, S.S., V.A. BAKALIN \& B.Y. SUN. 2012. Scapania and Macrodiplophyllum in the Russian Far East. - Botanica Pacifica 1: 31-95.

CRUM, H.A. 1972. A taxonomic account of the Erpodiaceae. - Nova Hedwigia 23: 201-224. 
DE LUNA, E. 1995. The circumscription and phylogenetic relationships of the Hedwigiaceae (Musci). - Systematic Botany 20(3): 347-373.

ELLIS, L.T., M. ALEFFI, A. ALEGRO, V. SEGOTA, A.K. ASTHANA, R. GUPTA, V.J. SINGH, V.A. BAKALIN, H. BEDNAREK-OCHYRA, B. CYKOWSKA-MARZENCKA, A. BENITEZ, E.A. BOROVICHEV, A.A. VILNET, N.A. KONSTANTINOVA, W. R. BUCK, C. CACCIATORO, C. SÉRGIO, J. CSIKY, J. DEME, D. KOVÁCS, K. DAMSHOLT, J. ENROTH, P. ERZBERGER, V.E. FEDOSOV, E. FUERTES, S.R. GRADSTEIN, N.J.M. GREMMEN, T. HALLINGBÄCK, I. JUKONIENË, T. KIEBACHER, J. LARRAÍN, M. LEBOUVIER, M. LÜTH, YU.S. MAMONTOV, A.D. POTEMKIN, CS. NEMETH, J.A.W. NIEUWKOOP, M. NOBIS, M. WEGGZYN, P. WIETRZYK, F. OSORIO, I. PARNIKOZA, V.M. VIRCHENKO, D. PERALTA, D.M. CARMO, V. PLÁŠEK, Z. SKOUPÁ, S. POPONESSI, R. VENANZONI, F. PUCHE, D. PURGER, C. REEB, R. RIOS, E. RODRIGUEZ-QUIEL, C. ARROCHA, M.S. SABOVLJEVIĆ, N. NIKOLIĆ, A.D. SABOVLJEVIĆ, E.L. DOS SANTOS, J.G. SEGARRA-MORAGUES, S. ȘTEFĂNUȚ \& D. STONČIUS. 2016. New national and regional bryophyte records, 48. - Journal of Bryology $\mathbf{3 8}$ (3): 235-259.

GOFFINET, B., W.R. BUCK \& A.J. SHAW. 2009. Morphology, anatomy and classification of the Bryophyta. - In: Goffinet, B. \& A.J. Shaw (eds.) Bryophyte Biology. Edition 2. Cambridge, Cambridge University Press: 55-138.

GRIFFIN, D.G. \& A.J. SHARP. 1971. Venturiella sinensis (Vent.) C.M. var. angusti-annulata var. nov., with floristic notes on the type locality. - Journal of the Hattori Botanical Laboratory 34: 398-402.

IGNATOV, M.S., E.A. IGNATOVA \& E.V. MALASHKINA. 2013. Ephemerum spinulosum Bruch \& Schimp. (Bryophyta), a new species for Russia. - Arctoa 22: 97-100.

IGNATOV, M.S., T. SUZUKI \& V. YA. CHERDANTSEVA. 2007. Fissidens hyalinus (Fissidentaceae, Bryophyta), a new species for Russia. - Arctoa 16: 123-126.

IGNATOVA, E.A., M.S. IGNATOV \& V. YA. CHERDANTSEVA. 2009. The genus Neckera (Neckeraceae, Bryophyta) in the Russian Far East. - Arctoa 18: 177-188.

[IVASHINNIKOV, YU.K.] ИВАШИННИКОВ Ю.К. 1999. Физическая география Дальнего Востока России. - [Physical geography of the Russian Far East] Владивосток: Изд-во Дальневосточного ун-та [Vladivostok, Izdatel 'stvo Dal'nevostochnogoUuniversiteta], 324 pp.

IWATSUKI, Z. 1972. Distribution of bryophytes common to Japan and the United States. - In: Graham, A. (ed.), Floristics and paleofloristics of Asia and Eastern North America. Elsevier, pp. 107-137.

[KOZHEVNIKOV, A.E. \& Z.V. KOZHEVNIKOVA] КОЖЕВНИКОВ А.Е., 3.В. КОЖЕВНИКОВА. 2014. Таксономический состав и особенности природной флоры Приморского края. - [Тахоnomic composition and special features of the natural flora in the Primorskii krai] Комаровские чтения [Komarovskiye Chteniya] 62: 7-62.

NOGUCHI, A. \& Z. IWATSUKI. 1988. Illustrated moss flora of Japan Part 2. - Hattori Botanical Laboratory: 243-491.

O'SHEA, B.J. 2006. Checklist of the mosses of sub-Saharan Africa (version 5, 12/06). - Tropical Bryology Research Reports 6: 1-252.

PRINTARAKUL, N., B.C. TAN, K. WONGKUNA-THANANOPPAKUN \& K. SANTANACHOTE. 2014. The Indian connection of the Thailand moss flora, with one new species, Fissidens elizbrowniae.Telopea 17: 195-215.

PURSELL, R.A. \& B.H. ALLEN. 2007. Erpodiaceae. - In: Flora of North America Editorial Committee (eds.). Flora of North America North of Mexico 27: 470-474.

REDFEARN, P.L. 1970. Bryophytes of the Interior Highlands XV. Additions to the Flora. - The Bryologist 73: 716-717.

REDFEARN, P.L. 1986. Bryogeography of the interior highlands of North America: taxa of critical importance. - The Bryologist 89(1): 32-34.

RICHARDSON, C. 2010. A new substrate and locality for Venturiella sinensis var. angusti-annulata in North America. - Evansia 27(4): 120.

SHARP, A.J., H.A. CRUM \& P.M. ECKEL. 1994. The moss flora of Mexico. - Memoirs of The New York Botanical Garden 69: 5811113

STONE, I.G. 1997. A revision of Erpodiaceae with particular reference to Australian taxa. - Journal of Bryology 19: 485-502.

SUZUKI, T. 2016. A revised new catalog of the mosses of Japan. - Hattoria 7: 9-223.

TAN, B.C. \& Z. IWATSUKI. 1996. Hot spots of mosses in East Asia. Anales del Instituto de Biologia serie Botanica 67(1): 159-167.

[VASILJEV, N.G., S.S. KHRKEVICH \& YU.B. SHIBNEV] ВАСИЛЬЕВ Н.Г., С.С. ХАРКЕВИЧ, Ю.Б. ШИБНЕВ. 1984. Заповедник “Кедровая падь". - [Kedrovaya Pad' Reserve] М.: Лесная промышленность [Moscow, Lesnaya Promyshlennost'], 198 pp.

VITT, D.H. 1984 Classification of the Bryopsida. - In: Schuster, R.M. (ed.). New Manual of Bryology 2. Nichinan: 696-760.

WANG, M.-Z. 2011. Erpodiaceae. - In: Moss Flora of China. Vol.5. Science Press \& Missouri Botanical Garden, Beijing, New York \& St. Louis, pp. 3-9.

WEN-ZHANG, M. \& J. R. SHEVOCK. 2015. The moss family Erpodiaceae in Yunnan Province, China. - Bryophyte diversity and evolution 37(1): 12-22.

WU, P.-C., M.R. CROSBY \& S. HE. 2011. Moss Flora of China. 5. Erpodiaceae-Climaciaceae. - In: Moss Flora of China. Science Press \& Missouri Botanical Garden, Beijing, New York \& St. Louis, viii+423 pp. 